\title{
MENIMBANG DEMOKRASI DELIBERATIF DALAM PROSES PEMBENTUKAN HUKUM YANG DEMOKRATIS DI INDONESIA
}

\begin{abstract}
Fadjar Sukma ${ }^{1}$, Saparuli $^{2}$
Sekolah Tinggi Ilmu Hukum IBLAM

Kramat Raya No.25, Senen, Jakarta Pusat

$\underline{\text { Fadjars21@gmail.com }}{ }^{1}$ saparuli7@gmail.com ${ }^{2}$

Abstract

Citizens as subjects as well as objects of law have an important role in the process of forming laws that apply as a model that becomes patterns of interaction in the life of the state and society as well as an order of behavior that must be fulfilled. This is also in line with the latent spirit of the Indonesian nation, namely "consensus" in making a decision or policy. But now democracy in Indonesia is only defined as the election of the president and vice president and representative institutions to sit in parliament. After that, public participation in various aspects of life seemed to be abolished, especially in terms of the formation of a regulation or law which actually directly affects people's lives, even though our constitution mandates that the highest power is in the hands of the people. A study on liberalized democracy popularized by Jurgen Hambermas emphasizes the active participation of the community as a pillar in direct supervision and inspection as well as on the formation of laws outside the parliament in order to direct the quality of Indonesian law towards a better direction.
\end{abstract}

Keywords :Law, Deliberative democracy, participation, society

\begin{abstract}
Abstrak
Warga negara sebagai subjek sekaligus sebagai objek dari hukum mempunyai peranan penting dalam proses pembentukan hukum yang berlaku sebagai sebuah model yang menjadi pola-pola interaksi dalam kehidupan bernegara dan bermasyarakat sekaligus menjadi sesuatu tatanan perilaku yang harus dipenuhi. Hal ini juga senada dengan semangat laten bangsa Indonesia yaitu "musyawarah-mufakat" dalam pengambilan sebuah keputusan atau kebijakan. Namun kini demokrasi di Indonesia hanya dimaknai sebatas pemilihan presiden dan wakil serta lebaga representatif untuk duduk di parlemen. setelah itu partisipasi masyarakat dalam berbagai aspek kehidupan seolah ditiadakan terutama dalam hal pembentukan sebuah peraturan atau hukum yang sejatinya berpengaruh langsung terhadap kehidupan masyarakat, padahal konstitusi kita mengamanatkan bahwa kekuasaan tertinggi ada ditangan rakyat. Sebuah kajian tentang demokrasi diliberalitatif yang dipopulerkan Jurgen Hambermas menekankan partisipasi aktif dari masyarakat sebagai pilar dalam pengawasan dan pemeriksaan langsung juga terhadap pembentukan hukum diluar parlemen guna mengarahkan kualitas hukum Indonesia kearah yang lebih baik.
\end{abstract}

Kata Kunci : Hukum, Demokrasi deliberatif, partispasi, masyarakat 


\section{A. Pendahuluan}

Gagasan demokrasi sebagai sistem nilai dan sistem politik mempunyai umur setua dengan gagasan tentang negara untuk pertama kali. Dimulai lebih dari 2500 tahun yang lalu, tepatnya pada tahun 508 SM, Kleistenes, seorang negarawan Yunani Kuno, mengadakan beberapa pembaruan dalam sistem pemerintahan kota Athena yang kemudian oleh sejarawan Herodotus (490-420 SM), diberi nama dengan "demokrasi". ${ }^{1}$ Pada zaman ini hampir setiap penduduk dapat turut serta dalam kehidupan politik, ekonomi, hukum atau budaya. Struktur sosial politik polis, dengan penduduk dan wilayah terbatas, menyediakan ruang partisipasi langsung bagi warga negara dalam keputusan yang menyangkut kepentingan bersama. ${ }^{2}$ Oleh karena itu Polis dianggap identik dengan masyarakat, dan masyarakat dianggap identik dengan negara (organisasi) yang masih berbentuk Polis Pada waktu itu, demokrasi yang dipraktekkan bersifat langsung (direct democracy); artinya hak rakyat untuk membuat keputusan-keputusan politik dijalankan secara langsung oleh seluruh warga negara yang bertindak berdasarkan prosedur mayoritas.

Ketentuan demokrasi hanya berlaku untuk warga negara resmi yang merupakan sebagian kecil dari seluruh penduduk. Sebagian besar yang terdiri dari budak belian, pegadang asing, perempuan dan anak-anak tidak dapat menikmati hak demokrasi. ${ }^{3}$ Demokrasi perwakilan yang terjadi di Indonesia baru berupa demokrasi perwakilan prosedural. Hubungan keterwakilan antara rakyat (konstituen) dengan wakil rakyat hanya bersifat semu. Tidak ada bargaining position (posisi tawar) yang proporsional antara konstituen dengan wakil rakyat. Konstituen di Indonesia belum menyadari perannya selaku rakyat yang memberikan sebagian kedaulatannya kepada negara melalui wakil rakyat. Konstituen belum menyadari bahwa langkah mereka tidak terhenti sampai memilih wakil rakyat. Konstituen pun belum menyadari bahwa dalam

1 Fahrul Muzaqqi, "Menimbang Gagasan Negara Hukum (Deliberatif) Di Indonesia," Wacana.Inddd, n.d., 175-98.

2 Pratiwi, "Publik Mencari Ruang Publik: Demokrasi Deliberatif Dan Manifestasi Penyaluran Kepentingan Masyarakat," Jurnal Wacana Kinerja Volume 14, no. 01 (2011): 47.

${ }^{3}$ Mahfud MD, Demokrasi Dan Konstitusi Di Indonesia (Rineka C, 2000). 
pelaksanaan fungsi DPR khusunya pembentukan undang-undang, mereka bisa menyuarakan kepentingan mereka dan mengingatkan DPR bahwa mereka dipilih oleh rakyat untuk melayani kepentingan rakyat. ${ }^{4}$

Sangat jelas bahwa keterlibatan masyarakat secara total menjadi instrumen utama dalam menjalankan sebuah sistem demokrasi, namun realitas yang terjadi kini sebaliknya dimana sebuah kebijakan lebih mengarah kepada kepentingan korporat atau bahkan segelintir elit yang berkepentingan. Begitupun dalam pembentukan hukum dimana kehendak atau aspirasi masyarakat tidak lagi diindahkan atau bahkan jauh dari kepentingan masyarakat luas. hal ini dapat kita temui sebagai contoh dimana penolakan besar terhadap UU Cipta Kerja terjadi dimana-dimana pada 2020 kemarin, artinya sebelum UU tersebut disahkan dan masyarakat dianggap tahu, masyarakat luas menolak dengan berbagai macam alasan. Akan tetapi UU tersebut tetap juga disahkan dan pada akhirnya masyarakat tahu dan dipaksa untuk patuh terhadap sebuah peraturan yang tidak dikehendaki. Kendati dalam Pasal 96 ayat (1) UU Nomor 12 Tahun 2011 tentang Pembentukan Peraturan Perundang-Undangan ${ }^{5}$, masyarakat berhak memberikan masukan secara lisan dan/atau tertulis dalam pembentukan peraturan perundangundangan. Dalam Peraturan Tata Tertib DPR RI juga diatur mengenai partisipasi masyarakat tepatnya dalam Bab XIV tentang Representasi Rakyat dan Partisipasi Masyarakat. Dalam ketentuan tata tertib ini juga disebutkan bahwa masyarakat dapat menyampaikan masukan kepada DPR (anggota maupun badan/alat kelengkapan) langsung maupun tertulis dalam hal: (i) penyusunan dan penetapan prolegnas; (ii) penyiapan dan pembahasan rancangan undang- undang; (iii)pembahasan RUU APBN; (iv) pengawasan pelaksanaan undang-undang; dan (v) pengawasan pelaksanaan kebijakan pemerintah. Di lain pihak, anggota DPR dapat menyerap aspirasi konstituennya melalui kunjungan kerja ataupun pembentukan rumah aspirasi di daerah pemilihannya (tempat konstituen mereka

\footnotetext{
${ }^{4}$ Wimmy Haliim, "Demokrasi Deliberatif Indonesia: Konsep Partisipasi Masyarakat Dalam Membentuk Demokrasi Dan Hukum Yang Responsif," Jurnal Masyarakat Indonesia 42, no. 1 (2016): 19-30.

5 "Undang-Undang Nomor 12 Tahun 2011 Tentang Pembentukan Peraturan PerundangUndangan".
} 
berada). Dan apabila mengacu pada UU Pembentukan Peraturan PerundangUndangan dan Peraturan Tata Tertib DPR, mekanisme pelibatan masyarakat hanya ditafsirkan melalui kunjungan kerja, rapat dengar pendapat, lokakarya, rumah aspirasi saat masa reses, dan sejenisnya. Mekanisme partisipasi yang ditawarkan ini bentuknya belum secara substansif mewakili kepentingan masyarakat. Menurut Sherry Arnstein, dalam bukunya A Ladder of Participation (1969) beberapa model partisipasi yang harus diwaspadai antara lain ${ }^{6}$ :

a. Partisipasi yang sifatnya manipulatif, yang hanya menempatkan elemen masyarakat dalam kerjasama yang sifatnya pembinaan atau kehumasan belaka.

b. Partisipasi yang menempatkan warga sebagai pihak yang harus diterapi karena kurangnya kapasitas diri dan aksesnya terhadap informasi. Misalnya warga yang melaporkan dampak kebijakan tertentu, alih-alih diselesaikan laporannya malah dirujuk ke institusi lain yang tugasnya mengelola pengaduan.

c. Partisipasi yang menempatkan warga sebagai target informasi. Meski inisiatif penginformasian harus diapresiasi, tetapi mekanismenya masih satu arah dan tidak bersifat dialogis. Informasi yang diberikan sifatnya masih pada permukaan belaka belum mengupayakan pemecahan masalah yang dialami warga.

d. Partisipasi sebagai salah satu model konsultasi publik. Dalam proses pengambilan keputusan, masyarakat sudah dilibatkan meski tidak ada jaminan masukan dari masyarakat akan dipertimbangkan dalam kebijakan yang diambil.

Maka dari apa yang telah dijabarkan diatas sangatlah jelas bahwa keterwakilan masyarakat dalam penentuan kebijakan atau bahkan pembentukan suatu peraturan perundang-undang masih bersifat semu dan tidak betul-betul terjadi dan komunikasi yang dilakukan pula masih bersifat satu arah tidak terjadi diskursus antar Lembaga perwakilan dengan yang diwakilinya.

\footnotetext{
6 M. Nur Sholikin, "Awasi Perda, Berdayakan Daerah Seri Panduan Pemantauan Legislasi Daerah," in Pusat Studi Hukum Dan Kebijakan Indonesia (Jakarta, 2009), 31-32.
} 
Hal ini tentu menjadi persoalan besar didalam kehidupan demokrasi kita padahal demokrasi kita masih terbilang muda pasca lepas dari rezim autokrasi ${ }^{7}$ yang membelenggu selama hampir 32 tahun. Di masa Orde Baru, dominasi negara atas masyarakat sangat kuat. Pengawasan negara atas masyarakat berjalan secara ekstensif. Campur tangan pemerintah ada di seluruh wilayah kehidupan seharihari. Kepala Desa diangkat sebagai klien negara yang mengontrol dan memantau hampir seluruh kegiatan masyarakat. ${ }^{8}$ Kini 20 tahun lebih setelah berakhirnya rezim tersebut cita-cita reformasi belum juga terwujud, angin segar terhadap partisiapasi publik dalam demokrasi belum juga berhembus. Demokrasi hanya dipahami dan diimplementasikan secara sempit, demokrasi hanya dimaknai sebagai hajatan 5 tahunan yang menjadi medan pertempuran dari para elit yang ingin meraih kekuasaan.

Demokrasi deliberatif yang ditawarkan Jurgen Habermas menjadi sumbangan pemikiran yang bisa dipertimbangkan untuk menyelesaikan persoalan demokrasi saat ini. Hal ini berdasarkan bahwa demokrasi deliberatif menyaratkan adanya komunikasi antara masyarakat dan negara (baca: pemimpin) yang diistilahkan dengan ruang publik (public sphere). ${ }^{9}$ Menurut Habermas, ruang publik adalah ruang yang memungkinkan seluruh anggota masyarakat dapat berinteraksi, bertukar pikiran, dan berdebat tentang masalah publik, tanpa perlu risau intervensi penguasa ekonomi dan politik. Melalui ruang publik pula, demokrasi bisa menemukan rakyat sebagai warga negara dan konstituen yang sadar hak dan kewajiban. Keadilan sosial, yang terwujud melalui konsensus bersama, idealnya diputuskan berdasar argumen terbaik. Habermas tidak meniadakan kuasa modal dan negara. Namun, ia menekankan kekuasaan komunikatif sebagai pengimbang kuasa administratif (negara) dan kekuasaan ekonomis (kapital). Publik dimaknai sebagai warga negara yang sadar akan hak dan kewajibannya. Partisipasi aktif

\footnotetext{
${ }^{7}$ Autokrasi adalah sistem pemerintahan yang kekuasaan politiknya dijalankan atau dikendalikan oleh satu orang

8 Thomas Mccarthy, THE THEORY OF LIFEWORLD AND SYSTEM: A CRITIQUE OF FUNCTIONALIST REASON Jiirgen Habermas, vol. 2, n.d.

9 Mohammad Asy'ari Muthhar, "Membaca Demokrasi Deliberatif Jurgen Habermas Dalam Dinamika Politik Indonesia," Ushuluna: Jurnal Ilmu Ushuluddin 2, no. 2 (2020): 49-72, https://doi.org/10.15408/ushuluna.v2i2.15180.
} 
publik mutlak diperlukan. ${ }^{10}$ Sebuah kajian mengenai kekuatan konstituen yang dapat membentuk hukum dapat kita lihat dalam sistem demokrasi deliberatif dan direct popular checks atau pemeriksaan langsung oleh masyarakat. Artinya, masyarakat ditempatkan sebagai sebuah pilar yang dapat mengawasi jalannya pemerintahan.

Pada hakikatnya, sistem ini merupakan sarana-sarana ultra-demokrasi yang merupakan perluasan proses legislatif di luar majelis yang dibentuk oleh masyarakat. Hal ini menjadi penting dalam rangka peningkatan kualitas demokrasi Indonesia. ${ }^{11}$ Salah satu ide mengenai keterlibatan masyarakat luas dalam menjalankan pemerintahan adalah demokrasi deliberatif seperti yang dikemukakan Jurgen Habermas. Tulisan ini mencoba menggali bagaimana konsep demokrasi deliberatif dapat mewujudkan hukum yang sesuai dengan kehendak dan realitas yang terjadi di masyarakat. Berdasarkan pertimbangan kemampuan penulis, metode kualitatif dengan penyajian deskriptif digunakan dalam penelitian ini. Sebagai alatnya, penulis menggunakan studi literatur terhadap teori demokrasi deliberatif yang di gagas oleh jurgen habermas.

\section{B. Hasil Penelitian dan Pembahasan}

\section{Demokrasi Delibaratif dalam proses pembentukan hukum}

Wacana tentang demokrasi delibarif di Indonesia sendiri bukanlah sesuatu yang baru, wacana ini berkembang di Indonesia setelah reformasi, hal ini mungkin disebabkan faktor bahwa kebebasan dan keterbukaan dalam berdemokrasi tidak dapat ditemukan pada masa orde baru. Demokrasi deliberatif sendiri menekankan pentingnya prosedur komunikasi untuk meraih legitimasi didalam sebuah proses yang dinamis antara sebuah sistem dan ruang publik yang dimobilisasi secara kultural sebuah sistem yang sesuai dengan proseduralitas negara hukum

\footnotetext{
${ }^{10}$ Pratiwi, "Publik Mencari Ruang Publik: Demokrasi Deliberatif Dan Manifestasi Penyaluran Kepentingan Masyarakat. Pratiwi, "Publik Mencari Ruang Publik: Demokrasi Deliberatif Dan Manifestasi Penyaluran Kepentingan Masyarakat," Jurnal Wacana Kinerja Volume 14, no. 01 (2011): 45."

${ }^{11}$ Haliim, "Demokrasi Deliberatif Indonesia : Konsep Partisipasi Masyarakat Dalam Membentuk Demokrasi Dan Hukum Yang Responsif."
} 
demokratis yang ada ${ }^{12}$. Demokrasi deliberatif di sini didefinisikan sebagai pandangan yang menempatkan deliberasi publik atas warga negara yang bebas dan setara sebagai inti legitimasi pembuatan keputusan politik dan pemerintahan sendiri.

Deliberasi sendiri sebagai sebuah terminologi berasal dari bahasa latin, yaitu deliberatio yang artinya menimbang-nimbang, konsultasi atau musyawarah. Artinya, terminologi itu menekankan proses pencapaian legitimasi atas keputusankeputusan politik yang dihasilkan oleh negara hendaknya melalui pengujian konsultasi publik, pertimbangan-pertimbangan multiperspektif dari publik atau sederhananya musyawarah, minimal melibatkan pihak-pihak yang nantinya akan menanggung atau terkena imbas dari keputusan politik tersebut. ${ }^{13}$ Demokrasi deliberatif tidak memusatkan pada aturan-aturan tertentu yang harus dilakukan oleh masyarakat melainkan pada prosedural aturan-aturan itu dibuat. Teori ini sendiri lebih menekankan kepada sebuah proses demokratisasi dengan sebuah pertanyaan besar dalam kondisi apa aturan-aturan ini dihasilkan sedemikian rupa sehingga para warga negara mematuhinya. Dengan kata lain teori ini memberi arti soal kontrol demokrasi.

Demokrasi deliberatif sendiri yang menurut jurgen Habermas merupakan jembatan penghubung antara warga negara dengan pemerintah dapat berlangsung dengan terciptanya ruang publik yang mampu menghasilkan sebuah diskursus komunikasi dalam pengambilan sebuah keputusan, sehingga keputusan yang dibuat itu sendiri menjadi autentik yang lahir dan sesuai dengan kehendak serta situasi dan kondisi yang ada tengah-tengah masyarakat itu sendiri. Apabila kita merujuk pada situasi hari ini dimana sebuah peraturan atau hukum itu sendiri jauh dari apa yang sebetulnya menjadi kebutuhan masyarakat banyak hal tersebut ditandai dengan berbagai macam bentuk penolakan yang dilakukan oleh warga negara terhadap sebuah peraturan perundang-undangan yang dibuat seperti RUU KUHP, RUU KPK sampai yang termasyur yaitu UU Cipta Kerja. Hal ini tentu

${ }^{12}$ F. Budi Hardiman, DEMOKRASI DELIBERATIF Menimbang "Negara Hukum Dan Ruang Publik" Dalam Teori Diskursus Jurgen Habermas (Yogyakarta: Penerbit Kanisius). 2009, hal 126 ${ }^{13}$ Fahrul Muzaqqi, "Diskursus Demokrasi Deliberatif Di Indonesia," Jurnal Review Politik 03 (2013): 123-39, http:/jurnalpolitik.uinsby.ac.id/index.php/jurnalpolitik/article/view/32. 
menjadi sebuah pertanyaan tentang eksistensi demokrasi perwakilan kita dan untuk siapa hukum atau peraturan perundang-undangan dibuat. Pada akhirnya kita dibenturkan dengan mekanisme yang dapat ditempuh dalam pengujian materii udang-undang (judicial review) ke Mahkamah Konstitusi. Yang mesti menjadi catatan adalah bahwa sejak tahun 2003 hingga kini jumlah perkara pengujian undang-undang yang masuk ke Mahkamah Konstitusi berjumlah $1475 .{ }^{14}$ hal ini menandakan bahwa undang-undang yang telah disahkan mendapat respon yang menegasikan bahwa undang-undang yang ada belum mampu merepresentasikan dan belum mengakomodasi kehendak masyarakat. Indikator tersebut dapat dibuktikan pada Undang-Undang Republik Indonesia Nomor 24 Tahun 2003 Tentang Mahkamah Konstitusi Pasal 51 (1) Pemohon adalah pihak yang menganggap hak dan/atau kewenangan konstitusionalnya dirugikan oleh berlakunya undang-undang ${ }^{15}$. Jurgen Habermas sendiri mengatakan bahwa undang-undang yang baik justru harus diuji didalam diskursus ruang publik untuk menentukan apakah peraturan perundang-undangan tersebut sesuai dengan kehendak dan mampu mengakomodasi masyarakat yang bersentuhan langsung dengan peraturan perundang-undangan tersebut. Dengan sistem demokrasi yang dianut Indonesia yaitu demokrasi perwakilan konsep keterwakilan itu musti diwujudkan dalam dialog atau diskursus antara rakyat dengan lembaga yang mewakilinya, namun apabila sebuah peraturan dibawa kepada sebuah lembaga yang berwenang untuk menguji kerugian konstitusional yang timbul karena peraturan atau undang-undang tersebut artinya manandakan bahwa ada ketimpangan dan tidak responsif lagi terhadap aspirasi dalam konsep keterwakilan tersebut sehingga menimbulkan defisit demokrasi yang dijelaskan lebih jauh oleh Sugeng Bahagijo (Associate Director Perkumpulan Prakarsa). Ia mengidentifikasi gejala defisit demokrasi yang melemahkan manfaat demokrasi di Indonesia meliputi: pertama, defisit representasi, di mana demokrasi yang ada lebih banyak

\footnotetext{
14 Mahkamah Konstitusi Republik Indonesia, "REKAPITULASI PERKARA PENGUJIAN UNDANG-UNDANG," $\quad$ accessed September 2021, https://www.mkri.id/index.php?page=web.RekapPUU\&menu=4.

15 “Undang-Undang Republik Indonesia Nomor 24 Tahun 2003 Tentang Mahkamah Konstitusi”.
} 
menyuarakan 'kelompok-kelompok kuat' apakah itu pengusaha atau politisi, sedangkan kelompok-kelompok sosial terutama mereka yang marjinal dan kaum perempuan belum memiliki keterwakilan secara memuaskan; kedua, memandang demokrasi sama dengan sistem demokrasi perwakilan, yakni hanya berpatok pada satu prosedur institusionl demokrasi seperti trias politika, pemilu, dan sebagainya dengan mengabaikan prinsip demokrasi langsung ataupun demokrasi deliberatif; ketiga, defisit akibat pendekatan demokrasi 'neoliberal constitualism' yang bercirikan, i) demokrasi tak lain adalah melindungi kebebasan pasar dengan dalih lebih efisien dan mampu mengatur alokasi sumber daya ketimbang negara/keputusan publik. ii) pembatasan pengambilan keputusan ekonomi negara dan peran negara dalam lapangan sosial dan ekonomi oleh pasar. iii) jika terjadi banyak ketimpangan, maka yang dicari adalah hambatan kepada pasar ketimbang distribusi atas barang sosial atau barang-barang publik semacam pendidikan, kesehatan dan pendapatan. Dari tiga defisit itu dia mengusulkan 'pendalaman demokrasi' meliputi: (1) pengembangan kelembagaan demokrasi langsung dengan model referendum, demokrasi deliberatif atau demokrasi assosiatif (demokrasi assosiatif berakar dari korporatisme Eropa, yakni adanya asosiasi-asosiasi masyarakat yang secara vertikal mewakili kelompok kepentingan semacam kelompok lingkungan, perempuan, kaum marjinal, produsen kecil, dan sebagainya); (2) penguatan rule of law dalam demokrasi berkaitan dengan hukum dan HAM; (3) melengkapi dengan sistem kuota sosial-ekonomi bagi kaum perempuan; (4) melengkapi dengan kelembagaan sosial ekonomi untuk mengawal jaminan-jaminan sosial-ekonomi semacam UMR, dan sebagainya. Dan apabila memperlukan lembaga lain dalam hal ini Mahkamah Konstitusi sebagai penentu dari sumbatan komunikasi tersebut.

Struktur-struktur komunikasi yang terkandang dalam konstitusi negara hukum demokratis dimengerti oleh Habermas sebagai sebuah proyek yang belum selesai namun dapat diwujudkan. Akan tetapi keadaan-keadaan empiris masyarakat yang begitu kompleks dewasa ini dapat didekatkan pada tujuan proyek itu haruslah ada model yang sesuai untuk demokrasi, sebuah model yang secara sosiologis dapat menjelaskan dinamika komunikasi politis didalam negara hukum demokratis yang 
ada. model yang sesuai dengan konsep proseduralistis tentang negara hukum itu adalah model demokrasi deliberatif. ${ }^{16}$

Keterlibatan masyarakat dalam berpartisipasi merupakan inti dari demokrasi deliberatif. Demokrasi deliberatif berbeda dengan demokrasi perwakilan, yang hari ini berlaku di Indonesia yang malah menjadi demokrasi prosedural semata. Gagasan keterlibatan masyarakat yang emansipatif merujuk pada proses komunikasi serta pencapaian konsensus di dalam forum-forum yang diselenggarakan di ruang publik di mana para partisipan didesak untuk melakukan proses komunikasi secara terbuka, setara dan menggunakan pendekatan musyawarah dalam mencapai sebuah kesepakatan yang menghargai opini mayoritas maupun minoritas

Komunikasi yang setara. Misal, saat terdapat satu pihak yang masih belum setuju, katakanlah masyarakat, maka forum proses publik tidak mampu dilanjutkan dan kesepakatan standar pelayanan publik tidak mampu disahkan oleh pejabat yang berwenang. Di sini, terdapat keseimbangan relasi kekuasaan, yang pada akhirnya akan mendesak orientasi dari para partisipan forum untuk mengedepankan kepentingan bersama, atau hal-hal yang lebih luas dari self interest maupun group interest nya masing-masing. ${ }^{17}$ Pemikiran Jurgen Habermas tentang tindakan komunikatif serta nalar berorientasi konsensus menjadi landasan teoritis, di mana Habermas menilai bahwa proses komunikasi harus setara demi tercapainya kesepakatan yang mampu diterima seluruh pihak, atau dengan kata lain, Habermas melihat integrasi sosial hanya mampu dicapai melalui proses tindakan komunikatif yang berujung pada pencapaian konsensus. Dalam hal ini, Habermas mencatat bahwa tindakan komunikatif harus dimaknai sebagai “...reach understanding [verstandigung] is considered to be a process of reaching agreement [einigung] among speaking and acting subjects... it has to be

\footnotetext{
${ }^{16}$ Hardiman, DEMOKRASI DELIBERATIF Menimbang "Negara Hukum Dan Ruang Publik” Dalam Teori Diskursus Jurgen Habermas. Hal 126

${ }^{17}$ Dodi Faedlulloh, Retnayu Prasetyanti, and - Indrawati, "Menggagas Ruang Publik Berbasis Demokrasi Deliberatif: Studi Dinamika Pengelolaan Ruang Publik Terpadu Ramah Anak (RPTRA) Di Jakarta Utara," Spirit Publik: Jurnal Administrasi Publik 12, no. 2 (2017): 43, https://doi.org/10.20961/sp.v12i2.16240.
} 
accepted or presupposed as valid by participants... a communicatively achieved agreement has a rational basis; it cannot be imposed by either party, whether instrumentally through intervention in the situation directly or strategically through influencing the decision of opponents..."18. Artinya Bahwa untuk mencapai sebuah pehamaman serta kesepakatan bersama antar subjek atau partisipan di dalam forum dapar berjalan, maka harus dipastikan bahwa komunikasi tersebut terlepas dari segala macam bentuk paksaan dari satu pihak karena apabila hal tersebut terjadi maka tidak akan menghasilkan sebuah konsesus dan hanya akan menjadi pemenuhan naluri dan tujuan-tujuan pribadi. Secara lebih lanjut Habermas menempuh jalan konsensus dengan sasaran terciptanya demokrasi radikal yaitu hubungan sosial yang terjadi dalam lingkup komunikasi bebas penguasaan. Dengan kata lain Habermas menggunakan pendekatan komunikatif yang diharapkan mambangun masyarakat serta sistem sosial yang komunikatif. ${ }^{19}$ masyarakat komunikatif bukanlah masyarakat yang melakukan kritik lewat revolusi dengan kekerasan, melainkan lewat argumentasi. Habermas justru menawarkan alternatif lain yaitu paradigma komunikatif yang bebas penguasaan, agar perubahan masyarakat tidak lagi melahirkan tirani baru, tidak melahirkan penindasan baru. Dalam konsepsi masyarakat komunikatif, Habermas menekankan pada terciptanya ruang dialogal yang bebas dari dominasi atau penguasaan satu pihak dengan tujuan agar terciptanya konsensus di tengah masyarakat. $^{20}$. Demokrasi deliberatif dalam kerangka pemikiran jurgen habermas menekankan pada bagiamana hukum yang terbentuk mendapatkan legitimasi yang berasal pada sebuah konsensus sebagai buah hasil dari proses diskursus yang bersifat intersubjektif. Apabila kita aplikasikan dalam prosedur-prosedur kekuasaan legislatif terutama dalam ranah pembentukan peraturan perundangundangan dengan menekankan prosedur komunikasi, maka kedaulatan rakyat

18 Jurgen Habermas, "The Theory of Communicative Action: Reason and The Rationalization Of Society," Volume I (Boston: Beacon Press, 1984), 67.

19 F Budi Hardiman, Kritik Ideologi; Menyingkap Pertautan Pengetahuan Dan Kepentingan Bersama Jurgen Habermas (Yogyakarta: Kanisius, 2009).

${ }^{20}$ F Budi Hardiman, Menuju Masyarakat Komunikatif: Ilmu, Masyarakat, Politik Dan Posmodernisme Menurut Jürgen Habermas (Yogyakarta: Kanisius, 1993). 
tidaklah dipahami sebagai sesuatu yang eksklusif yang hanya ter-alienasi di wilayah lembaga legislatif saja. Kedaulatan rakyat dengan menekankan prosedur komunikasi adalah upaya untuk menjaring segala macam bentuk keanekaragaman dan berbagai aspirasi yang lahir dari dinamika kehidupan yang terjadi di tengah masyarakat. Disinilah letak kekuasaan legislatif tersebut sebagai sebuah prosedur komunikasi. Kemajemukan gerakan- gerakan aspiratif dalam berbagai bentuk ruang publik (termasuk DPR) menyumbangkan sudut-sudut pandang yang berbeda-beda, dan suara-suara aspiratif mereka membentuk jaringan-jaringan komunikasi yang bersifat masif yang mesti diperhitungkan oleh para penguasa administratif. Dengan kata lain, proseduralisasi ide kedaulatan rakyat tak lain daripada multiplikasi dan pluralisasi pusat-pusat deliberasi politis dan penyebaran hak-hak komunikasi dan hak-hak partisipasi. Demokrasi Deliberatif hendak menembus eksklusivitas proses deliberasi dalam parlemen dan memperluasnya hingga ke batas akhir ruang publik. ${ }^{21}$ Demokrasi deliberatif memberikan sorotan tajam mengenai bagaimana prosedur hukum itu dibentuk. Undang-undang, yang diresmikan dalam demokrasi deliberatif, merupakan suatu dialog antara mekanisme legislatif dan diskursus-diskursus, baik formal maupun informal, dalam dinamika masyarakat sipil. Demokrasi deliberatif memberikan ruang di luar kekuasaan administratif negara. Ruang itu merupakan jaringan-jaringan komunikasi publik dalam ma- syarakat sipil. Terdapat korelasi yang jelas antara gagasan demokrasi dan ide demokrasi deliberatif, yaitu menempatkan masyarakat pada posisi yang emansipatoris untuk melakukan kegiatan legislasi melalui ruangruang publik. Pembuatan hukum menurut Habermas tidak dapat dilakukan dalam keadaan splendid isolation suasana rahasia yang tertutup dari tatapan kritis publik. Dalam Pasal 21 ayat (3) dan (4) Undang-Undang Nomor 12 Tahun 2011, dijelaskan bahwa Prolegnas ditentukan dalam ruang lingkup DPR dan pemerintah.

Dalam ruang lingkup DPR, dilakukan dengan mempertimbangkan usulan dan pandangan anggota DPR, fraksi, komisi, gabungan fraksi, dan masyarakat.

${ }^{21}$ Fajar Ahmad Setiawan, Ani Purwanti, and Lita Tyesta A.L.W, "Peran Anggota DPRD Perempuan Dalam Pembentukan Kebijakan Di Dewan Perwakilan Rakyat Daerah Provinsi Jawa Tengah Berbasis Demokrasi Deliberatif," Diponegoro Law Journal 5, no. 3 (2016): 1-20. 
Pertimbangan atas usulan masyarakat ini seharusnya dilaksanakan melalui mekanisme tersendiri terlepas dalam pengaturan ruang lingkup DPR. Hal ini dilakukan untuk mencegah adanya splendid isolation dalam penyusunan Prolegnas. Seharusnya terdapat ketentuan bahwa, dalam penyusunan Prolegnas, badan-badan yang ditunjuk oleh DPR harus melaksanakan debat publik ihwal kebutuhan hukum masyarakat karena kebutuhan hukum masyarakat merupakan dasar penyusunan Prolegnas. Hal ini ditegaskan dalam Pasal 18 huruf h UU No. 12 Tahun 2011. ${ }^{22}$ Sebuah kajian mengenai kekuatan konstituen yang dapat membentuk hukum dapat kita lihat dalam sistem direct popular checks atau pemeriksaan langsung oleh masyarakat. Direct popular checks juga merupakan bentuk kesepakatan penulis dengan gagasan demokrasi deliberatif Habermas dalam membentuk hukum yang responsif. Artinya, masyarakat ditempatkan sebagai sebuah pilar yang dapat mengawasi jalannya pemerintahan. ${ }^{23}$ Pada hakikatnya, sistem ini merupakan sarana-sarana ultra demokrasi yang merupakan perluasan proses legislatif di luar majelis yang dibentuk oleh masyarakat.

\section{Penutup}

Gagasan tentang demokrasi deliberatif yang dikemukakan oleh jurgen habermas ini merupakan sebuah tawaran untuk menjadi rujukan pembentukan hukum di Indonesia guna untuk menciptakan hukum yang responsif yang berakar dari keterlibatan atau partisipasi dari masyarakat luas. Melalui prosedural komunikatif itu terbentuk lewat pengakuan faktual atas klaim-klaim kesahihan yang terbuka terhadap kritik dan dicapai secara diskursif. Dengan kata lain, legitimitasi suatu keputusan publik diperoleh lewat pengujian publik dalam proses deliberasi yang menyambungkan aspirasi rakyat dalam ruang publik dan proses legislasi hukum oleh lembaga legislatif dalam sistem politik. Dengan menciptakan ruang komunikasi yang baik untuk masyarakat akan memberikan posisi tawar yang lebih bagi masyarakat terhadap legilatif untuk terciptanya hukum yang

${ }^{22}$ Haliim, "Demokrasi Deliberatif Indonesia: Konsep Partisipasi Masyarakat Dalam Membentuk Demokrasi Dan Hukum Yang Responsif."

${ }^{23}$ Strong C F, The Modern Political Constitutions (London: The English Language Book Society, 1973). 
benar-benar sesuai dengan kehendak dan dinamika realitas yang terjadi di tengahtengah masyarakat, hal tersebut tentunya selaras dengan spirit bangsa Indonesia yang tertuang dalam sila ke4 "Kerakyatan yang dipimpin oleh hikmat kebijaksanaan dalam permusyawaratan perwakilan".

Disamping itu keterlibatan secara aktif masyarakat dalam menentukan dan merumuskan sebuah aturan yang akan berlaku baginya juga merupakan vitamin bagi kehidupan demokrasi kita dimana kedualatan rakyat termanifestasikan secara riil tidak serta merta didistribusikan kepada lembaga-lembaga negara. Bagaimana masyarakat ikut menentukan sebuah peraturan atau ketentuan yang akan dijalankan bahkan ikut aktif dalam segala arah kebijakan negara merupakan bentuk kedaulatan rakyat yang nyata.

\section{Daftar Pustaka}

F, Strong C. The Modern Political Constitutions. London: The English Language Book Society, 1973.

Faedlulloh, Dodi, Retnayu Prasetyanti, and - Indrawati. "Menggagas Ruang Publik Berbasis Demokrasi Deliberatif: Studi Dinamika Pengelolaan Ruang Publik Terpadu Ramah Anak (RPTRA) Di Jakarta Utara." Spirit Publik: Jurnal Administrasi Publik 12, no. 2 (2017): 43. https://doi.org/10.20961/sp.v12i2.16240.

Habermas, Jurgen. "The Theory of Communicative Action: Reason and The Rationalization Of Society," Volume I., 67. Boston: Beacon Press, 1984.

Haliim, Wimmy. "Demokrasi Deliberatif Indonesia: Konsep Partisipasi Masyarakat Dalam Membentuk Demokrasi Dan Hukum Yang Responsif." Jurnal Masyarakat Indonesia 42, no. 1 (2016): 19-30.

Hardiman, F. Budi. DEMOKRASI DELIBERATIF Menimbang "Negara Hukum Dan Ruang Publik” Dalam Teori Diskursus Jurgen Habermas. Yogyakarta: Penerbit Kanisius, n.d.

Hardiman, F Budi. Kritik Ideologi; Menyingkap Pertautan Pengetahuan Dan Kepentingan Bersama Jurgen Habermas. Yogyakarta: Kanisius, 2009.

—. Menuju Masyarakat Komunikatif: Ilmu, Masyarakat, Politik Dan Posmodernisme Menurut Jürgen Habermas. Yogyakarta: Kanisius, 1993.

Indonesia, Mahkamah Konstitusi Republik. "REKAPITULASI PERKARA PENGUJIAN UNDANG-UNDANG.” Accessed September 2, 2021. https://www.mkri.id/index.php?page=web.RekapPUU\&menu=4.

Mccarthy, Thomas. THE THEORY OF Volume 2 LIFEWORLD AND SYSTEM : A CRITIQUE OF FUNCTIONALIST REASON Jiirgen Habermas. Vol. 2, n.d.

MD, Mahfud. Demokrasi Dan Konstitusi Di Indonesia. Rineka C, 2000.

Muthhar, Mohammad Asy'ari. "Membaca Demokrasi Deliberatif Jurgen 
Habermas Dalam Dinamika Politik Indonesia." Ushuluna: Jurnal Ilmu $\begin{array}{lllll}\text { Ushuluddin } & 2, & \text { no. } & 2 & \text { (2020): }\end{array}$ https://doi.org/10.15408/ushuluna.v2i2.15180.

Muzaqqi, Fahrul. "Diskursus Demokrasi Deliberatif Di Indonesia." Jurnal Review

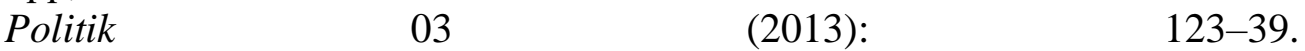
http://jurnalpolitik.uinsby.ac.id/index.php/jurnalpolitik/article/view/32.

—. "Menimbang Gagasan Negara Hukum (Deliberatif) Di Indonesia." Wacana.Inddd, n.d., 175-98.

Pratiwi. "Publik Mencari Ruang Publik : Demokrasi Deliberatif Dan Manifestasi Penyaluran Kepentingan Masyarakat." Jurnal Wacana Kinerja Volume 14, no. 01 (2011): 47.

Setiawan, Fajar Ahmad, Ani Purwanti, and Lita Tyesta A.L.W. "Peran Anggota DPRD Perempuan Dalam Pembentukan Kebijakan Di Dewan Perwakilan Rakyat Daerah Provinsi Jawa Tengah Berbasis Demokrasi Deliberatif." Diponegoro Law Journal 5, no. 3 (2016): 1-20.

Sholikin, M. Nur. "Awasi Perda, Berdayakan Daerah Seri Panduan Pemantauan Legislasi Daerah.” In Pusat Studi Hukum Dan Kebijakan Indonesia, 31-32. Jakarta, 2009.

Undang-Undang Nomor 12 Tahun 2011 tentang Pembentukan Peraturan Perundang-Undangan (n.d.).

Undang-Undang Republik Indonesia Nomor 24 Tahun 2003 Tentang Mahkamah Konstitusi (n.d.). 